\title{
Antimicrobial peptides for Gram-negative sepsis: a case for the polymyxins
}

\author{
Sunil A. David* \\ Department of Medicinal Chemistry, University of Kansas, Lawrence, KS, USA \\ ${ }^{*}$ Correspondence: sdavid@ku.edu \\ Edited by: \\ Mark W. Robinson, Queen's University, Northern Ireland \\ Reviewed by: \\ Mark W. Robinson, Queen's University, Northern Ireland
}

Sepsis, or "blood poisoning" in lay terminology, is a common and serious clinical problem. While fewer than 100 cases were reported prior to 1920 (Felty and Keefer, 1924), it is now the 13th leading cause of overall mortality (Gelfand and Shapiro, 1993) and the number one cause of deaths in the intensive care unit accounting for some 200,000 fatalities in the US annually. The incidence continues to rise in the US (Martin et al., 2003; Figure 1) and worldwide (Moss and Martin, 2004), perhaps due to increased invasive procedures, immunosuppression, and cytotoxic chemotherapy. Mortality associated with sepsis, unfortunately, has essentially remained unchanged at about 45\% (Cross and Opal, 1994), despite tremendous strides in antimicrobial chemotherapy, pointing to the absence of therapeutic strategies aimed specifically at the pathophysiology of sepsis. The pathophysiology of the disease is characterized by a systemic inflammatory response syndrome (SIRS), culminating in its frequently fatal sequel, multiple organ dysfunction syndrome (MODS). The systemic inflammatory response is a consequence of dysregulated activation of innate immune effector mechanisms (Castellheim et al., 2009). Counterregulatory mechanisms that are subsequently deployed to dampen the initial overexuberant systemic inflammatory responses are also thought to contribute to the pathophysiology due to late-stage immunosuppressive (hypoinflammatory) phenomena, which render the host unable to eradicate the offending pathogen (Hotchkiss and Karl, 2003; Hotchkiss et al., 2009).

The primary trigger of SIRS in the Gramnegative septic shock syndrome is thought to be endotoxin, a constituent of the outer membrane of all Gram-negative bacteria. Endotoxins consist of a polysaccharide portion and a lipid called lipid A, and are therefore also called lipopolysaccharides (LPS). The polysaccharide portion consists of an O-antigen-specific polymer of repeating oligosaccharide units, the composition of which is highly varied among Gram-negative bacteria. A relatively wellconserved core hetero-oligosaccharide covalently bridges the $\mathrm{O}$-antigen-specific chain with lipid A (Rietschel et al., 1994). Total synthesis of the structurally highly conserved lipid A has been shown to be the active moiety of LPS (Rietschel et al., 1987).

Whereas LPS itself is chemically inert, the presence of LPS in blood (endotoxemia), often a consequence of antibiotic therapy of preexisting bacterial infections (Holzheimer, 2001), is recognized by Tolllike receptor 4 (TLR4; Beutler and Poltorak, 2001; Palsson-McDermott and O'Neill, 2004; Hennessy et al., 2010), a member of a large super-family of pattern recognition receptors (Jounai et al., 2012; Newton and Dixit, 2012; Olive, 2012). Endotoxemia and its sequelae may arise even in the absence of Gram-negative bacterial infections, conditions such as trauma (Saadia et al., 1990), burns (Jones II et al., 1991), and splanchnic ischemia during cardiac surgery (Rocke et al., 1987) increase intestinal permeability, resulting in the spill-over into the portal circulation of LPS from the colon which is abundantly colonized by Gram-negative bacteria. The sensing of LPS, "read by our tissues as the very worst of bad news" (Thomas, 1975), results in a cascade of exaggerated host responses, manifesting in the clinical syndrome characterized by endothelial damage, coagulopathy, loss of vascular tone, myocardial dysfunction, tissue hypoperfusion, and multiple-system organ failure (Balk and Bone, 1989; Bone et al., 1992; Bone, 1993). LPS activates almost every component of the cellular and humoral (plasma protein) limbs of the immune system, resulting in the production of a plethora of proinflammatory mediators, important among which are not only early-phase cytokines such as tumor necrosis factor- $\alpha$ (TNF- $\alpha)$, interleukin- $1 \beta$ (IL-1 $\beta$ ), and IL-6 (Dinarello, 1991, 1996) but also late-phase endogenous mediators such as high mobility group box 1 protein (HMGB1; (Wang et al., 1999; Andersson and Tracey, 2011). These cytokines and other mediators act in concert, amplifying the resultant generalized inflammatory processes.

Our understanding of basic mechanisms underlying the cellular response to LPS has increased vastly in recent years. These advances will likely offer novel therapeutic possibilities in the future. However, after more than two decades of intensive effort at evaluating more than 30 investigational compounds, specific therapeutic options for sepsis have remained elusive. Drotrecogin alfa Xigris $^{\mathrm{TM}}$, recombinant human activated protein $\mathrm{C}$ ), an anticoagulant that ameliorates disseminated intravascular coagulation was approved in November 2001 by the FDA, but recently withdrawn due to lack of efficacy (Ranieri et al., 2012; Wenzel and Edmond, 2012). Clinical trials aimed at blocking various proinflammatory mediators including TNF- $\alpha$, IL-1 $\beta$, platelet-activating factor, and prostaglandins produced by the activated cellular components have all been disappointing (Zeni et al., 1997), suggesting that targeting downstream cellular inflammatory processes once immune activation has already progressed is unlikely to be of benefit.

It follows, therefore, that the paradigm of proximal, upstream intervention using molecules that specifically block the recognition of LPS by TLR4 would offer attractive therapeutic targets. As mentioned 


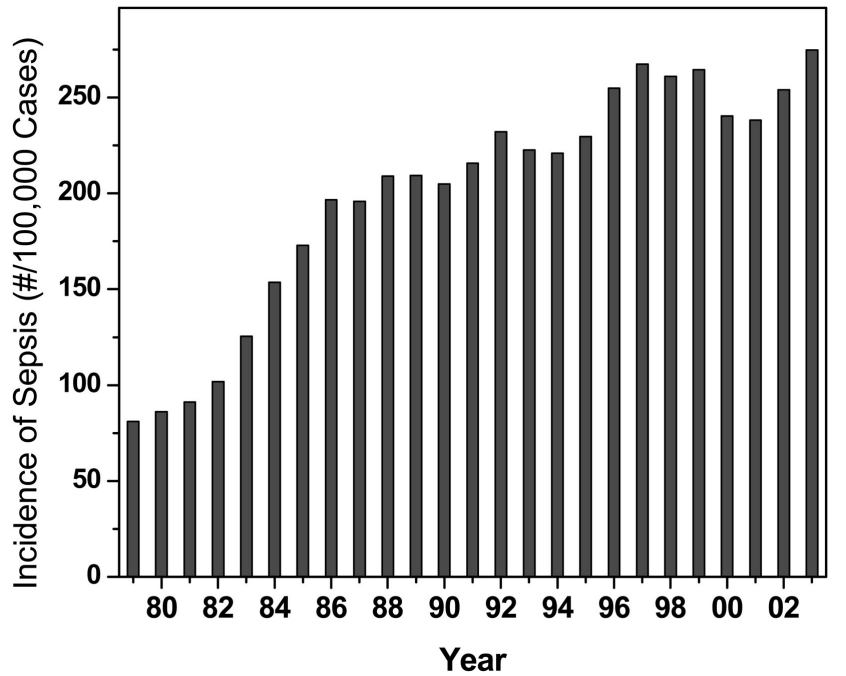

FIGURE 1 | Incidence of sepsis in the US Data provided by Greg Martin.

earlier, the polysaccharide portion of LPS is highly variable and serologically distinct for each strain of the same species of Gram-negative organisms. Although antiO-polysaccharide antibodies afford protection in experimental models where animals are challenged with homologous bacteria (Kim et al., 1988; Siegel, 1995), these are not likely to be of significant clinical value since sepsis runs an acute course before the pathogen is identified and appropriate specific immunotherapy is instituted. The biologically active part of LPS, lipid A, as well as the core oligosaccharide portion are structurally highly conserved across Gramnegative genera, and thus are attractive targets for sequestration, and elimination of circulating LPS would, in principle, prevent the activation of inflammatory cascades (Ziegler et al., 1982; Ziegler, 1988; Ziegler and Smith, 1992). Experimental studies as early as 1968 suggested that antibodies directed toward epitopes in the core region of LPS may be broadly cross-protective against a range of Gram-negative organisms (Chedid et al., 1968). However, neither human (HA-1A; (Ziegler et al., 1991) nor murine (E5; (Bone et al., 1995) antilipid A monoclonal antibodies afforded significant protection in large, multiple, placebo-controlled clinical trials (Cross and Opal, 1994). Similarly disappointing results were obtained with core regiondirected antibodies (Di Padova et al., 1993; Le Roy et al., 1999). Taken together, these failures could point to intrinsic problems with lipid antigens: poor immunogenicity, inaccessibility of neutralizing epitopes, the generation of non-specific cross-reactive antibodies against irrelevant hydrophobic epitopes (Vaarala et al., 1988), and potential problems with the antibody molecule itself: predominant intravascular compartmentalization, and possible tissue damage induced by activation of complement. Non-immunological blockade of LPS recognition using TLR4 "blockers" is therefore an alternative strategy, a premise that has indeed been explored with molecules structurally related to lipid A, but acting as TLR4-specific antagonists (Christ et al., 1995; Kawata et al., 1999; Wittebole et al., 2010; Ehrentraut et al., 2011; Tidswell and Larosa, 2011), but unfortunately, do not appear promising (Williams, 2012). It is not known whether the lack of efficacy is attributable to its physicochemical properties (high lipophilicity; (Christ et al., 1995) and consequent partitioning into plasma lipoproteins, with loss of activity (Rose et al., 2000).

As mentioned earlier, the structurally invariant and biologically active center of LPS, lipid A, is a logical therapeutic target for neutralization. Lipid A is composed of a hydrophilic, negatively charged bis-phosphorylated di-glucosamine backbone, and a hydrophobic domain of six (E. coli) or seven (Salmonella) acyl chains. The anionic amphiphilic nature of lipid A enables it to interact with a variety of cationic hydrophobic ligands (Vaara and Vaara, 1983;
Peterson et al., 1985; Rocque et al., 1988). Polymyxin B (PMB), a cationic amphiphilic cyclic decapeptide antibiotic isolated from Bacillus polymyxa (Storm and Rosenthal, 1977), has long been recognized to bind lipid A (Morrison and Jacobs, 1976), and neutralize its toxicity in animal models of endotoxemia (Stokes et al., 1989; Durando et al., 1994; Yao et al., 1995). Although PMB is a commonly used topical antibiotic, it is nephro- and oto-toxic, which, while hitherto precluding its use as an LPS-neutralizer in patients with sepsis, has stimulated the search for non-toxic PMB analogs (Rustici et al., 1993; Porro et al., 1998), PMB derivatives (Vaara, 1983; Viljanen et al., 1991), as well as other structurally diverse cationic amphiphilic peptides (Rustici et al., 1993; Porro, 1994; Iwagaki et al., 2000; Scott et al., 2000; Jerala and Porro, 2004) as candidate LPS-binding agents. Notably, a hemoperfusion cartridge based on PMB covalently immobilized via one of its $\mathrm{NH}_{2}$ groups to a polystyrene based fiber became available in Japan in late 2000 for clinical use ("Toraymyxin ${ }^{\mathrm{TM}}$," Toray Industries Inc., Tokyo; (Nakamura et al., 1999, 2002, 2003). In the EUPHAS randomized clinical trial, PMB hemoperfusion alongside conventional therapy was found to improve organ dysfunction and reduce 28-days mortality in subsets of patients with sepsis arising from intra-abdominal Gram-negative infections (Cruz et al., 2009). Whilst the utility of Toraymyxin provides a clinically validated proof-of-principle for the value of sequestering circulating LPS (Rimmele and Kellum, 2011), opportunities for extracorporeal hemoperfusion may be infrequent due to unfavorable hemodynamic parameters.

Given that the only encouraging lead for the management of sepsis to date appears to be $\mathrm{PMB}$ hemofiltration, it is perhaps useful to re-examine PMB itself, as well as its structurally closely related congener, polymyxin $\mathrm{E}$ (or colistin). PMB and polymyxin E differ one from the other by a single amino acid (D-Phe in PMB; D-Leu in PME; (Kwa et al., 2007), and are similar in their in vitro antimicrobial activity, clinical efficacy, and toxicity (Oliveira et al., 2009). Although banished to a topical-use-only status on account of its systemic toxicity, the polymyxins are rapidly re-emerging as last-resort parenteral antibiotics for the management of infections with extensive drug resistant 
strains of Pseudomonas aeruginosa (Zavascki et al., 2007; Michalopoulos and Falagas, 2008; Giamarellou and Poulakou, 2009), Acinetobacter baumannii (Gales et al., 2011; Fitzpatrick et al., 2012), and Burkholderia species (Gales et al., 2011). The increased use of these peptide antibiotics has led to a careful re-examination of its purported toxicity (Falagas and Kasiakou, 2006). Evaluation in diverse clinical settings (Ramasubban et al., 2008; Nation and Li, 2009; Lim et al., 2010; Durakovic et al., 2011; Spapen et al., 2011; Cho et al., 2012) indicate that tolerability of the antibiotic is acceptable, and the toxicity is less than previously thought. Of particular interest is a recent report (Mizuyachi et al., 2011) detailing the safety and pharmacokinetic evaluation of intravenous colistin as the methanesulfonate prodrug (Bergen et al., 2006) in healthy human volunteers. Urinary $N$-acetyl- $\beta$-D-glucosaminidase (a biomarker for early renal damage) showed only transient and reversible increases at doses eliciting plasma concentrations (free area under the concentration-time curve/ MIC) of drug that were predicted to be bactericidal (Mizuyachi et al., 2011). Since the antimicrobial effects of the polymyxins are a direct consequence of their binding to lipopolysaccharide (Morrison and Jacobs, 1976; Nikaido and Vaara, 1985), it is reasonable to assume that the plasma concentration of the drug would be of such magnitude as to be sufficient for sequestering LPS.

Erasmus' adage, "Malo nodo, malus quoerendus cuneus" (for a hard knot a hard tool must be sought), rings perhaps particularly true for sepsis for which a single tractable lead toward a validated therapeutic approach is yet to be found, mortality continues to be unacceptably high, and a survey of the research landscape in the field conjures up images of a bleak battlefield strewn with the corpses of many a failed approach. The venerable polymyxins, never subjected to modern regulatory requirements when they were first introduced, and exiled for the last 50 years, are making their way back into the clinic as parenteral antibiotics. Much is being learned as they are re-examined with the rigor and precision of modern methods of pharmacokinetic (Couet et al., 2012) and pharmacodynamic (Mizuyachi et al., 2011) analyses. Perhaps there is a case to be made for a careful risk-benefit evaluation of the polymyxins in Gram-negative sepsis.

\section{ACKNOWLEDGMENTS}

The author gratefully acknowledges support from the NIH (Grants 1U01AI077947, 1R01 AI050107, 1U01 AI054785, 1U01 AI056476, and 1R03 AI055725).

\section{REFERENCES}

Andersson, U., and Tracey, K. J. (2011). HMGB1 is a therapeutic target for sterile inflammation and infection. Annu. Rev. Immunol. 29, 139-162.

Balk, R. A., and Bone, R. C. (1989). The septic syndrome. Definition and clinical implications. Crit. Care Clin. $5,1-8$.

Bergen, P. J., Li, J., Rayner, C. R., and Nation, R. L. (2006). Colistin methanesulfonate is an inactive prodrug of colistin against Pseudomonas aeruginosa. Antimicrob. Agents Chemother. 50, 1953-1958.

Beutler, B., and Poltorak, A. (2001). The sole gateway to endotoxin response: how LPS was identified as TLR4, and its role in innate immunity. Drug Metab. Dispos. 29, 474-478.

Bone, R. C. (1993). Gram-negative sepsis: a dilemma of modern medicine. Clin. Microbiol. Rev. 6, 57-68.

Bone, R. C., Balk, R. A., Fein, A. M., Perl, T. M., Wenzel, R. P., Reines, H. D., Quenzer, R.W., Iberti, T. J., Macintyre, N., and Schein, R. M. (1995). A second large controlled clinical study of E5, a monoclonal antibody to endotoxin: results of a prospective, multicenter, randomized, controlled trial. The E5 sepsis study group. Crit. Care Med.23, 994-1006. [see comments]

Bone, R. C., Sprung, C. L., and Sibbald, W. J. (1992). Definitions for sepsis and organ failure. Crit. Care Med. 20, 724-726.

Castellheim, A., Brekke, O. L., Espevik, T., Harboe, M., and Mollnes, T. E. (2009). Innate immune responses to danger signals in systemic inflammatory response syndrome and sepsis. Scand. J. Immunol. 69, 479-491.

Chedid, L., Parant, M., and Parant, F. (1968). A proposed mechanism for natural immunity to enterobacterial pathogens. J. Immunol. 100, 292-306.

Cho, Y. S., Yim, H., Yang, H. T., Hur, J., Chun, W., Kim, J. H., Lee, B. C., Seo, D. K., Park, J. M., and Kim, D. (2012). Use of parenteral colistin for the treatment of multiresistant Gram-negative organisms in major burn patients in South Korea. Infection 40, 27-33.

Christ, W. J., Asano, O., Robidoux, A. L. C., Perez, M., Wang, Y., Dubuc, G. R., Gavin, W. E., Hawkins, L. D., McGuinness, P. D., Mullarkey, M. A., Lewis, M. D., Kishi, Y., Kawata, T., Bristol, J. R., Rose, J. R. Rossignol, D. P., Kobayashi, S., Hishinuma, I., Kimura, A., Asakawa, N., Katayama, K., and Yamatsu, I. (1995). E5531, a pure endotoxin antagonist of high potency. Science 268, 80-83.

Couet, W., Gregoire, N., Marchand, S., and Mimoz, O. (2012). Colistin pharmacokinetics: the fog is lifting. Clin. Microbiol. Infect. 18, 30-39.

Cross, A., and Opal, S. M. (1994). Therapeutic intervention in sepsis with antibody to endotoxin: is there a future? J. Endotoxin Res. 1, 57-59.

Cruz, D. N., Antonelli, M., Fumagalli, R., Foltran, F., Brienza, N., Donati, A., Malcangi, V., Petrini, F., Volta, G., Bobbio Pallavicini, F. M., Rottoli, F., Giunta, F., and Ronco, C. (2009). Early use of polymyxin B hemoperfusion in abdominal septic shock: the EUPHAS randomized controlled trial. JAMA 301, 2445-2452.

Di Padova, F., Brade, H., Barclay, G. R., Poxton, I. R., Liehl, E., Schuetze, E., Kocher, H.P., Ramsay, G., Schreier, M.
H., McClelland, D. B. L., and Rietschel, E. T. (1993). A broadly cross-protective monoclonal antibody binding to Escherichia coli and Salmonella lipopolysaccharide. Infect. Immun. 61, 3863-3872.

Dinarello, C. A. (1991). The proinflammatory cytokines interleukin-1 and tumor necrosis factor and treatment of the septic shock syndrome. J. Infect. Dis. 163, 1177-1184.

Dinarello, C. A. (1996). Cytokines as mediators in the pathogenesis of septic shock. Curr. Top. Microbiol. Immunol. 216, 133-165.

Durakovic, N., Radojcic, V., Boban, A., Mrsic, M., Sertic, D., Serventi-Seiwerth, R., Nemet, D., and Labar, B. (2011).Efficacy and safety of colistin in the treatment of infections caused by multidrug-resistant Pseudomonas aeruginosa in patients with hematologic malignancy: a matched pair analysis. Intern. Med. 50, 1009-1013.

Durando, M. M., MacKay, R. J., Linda, S., and Skelley, L. A. (1994). Effects of polymyxin B and Salmonella typhimurium antiserum on horses given endotoxin intravenously. Am. J. Vet. Res. 55, 921-927.

Ehrentraut, S., Lohner, R., Schwederski, M., Ehrentraut, H., Boehm, O., Noga, S., Langhoff, P., Baumgarten, G., Meyer, R., and Knuefermann, P. (2011). In vivo tolllike receptor 4 antagonism restores cardiac function during endotoxemia. Shock 36, 613-620.

Falagas, M. E., and Kasiakou, S. K. (2006). Toxicity of polymyxins: a systematic review of the evidence from old and recent studies. Crit. Care 10, R27.

Felty, A. R., and Keefer, C. S. (1924). Bacillus coli sepsis: a clinical study of twenty-eight cases of bloodstream infection by the colon bacillus. JAMA 82, 1430-1433.

Fitzpatrick, M.A., Esterly, J.S., Postelnick, M.J., and Sutton, S.H. (2012). Successful treatment of extensively drugresistant Acinetobacter baumannii peritoneal dialysis peritonitis with intraperitoneal polymyxin B and ampicillin-sulbactam. Ann. Pharmacother. 46, e17.

Gales, A. C., Jones, R. N., and Sader, H. S. (2011). Contemporary activity of colistin and polymyxin $B$ against a worldwide collection of Gram-negative pathogens: results from the SENTRY antimicrobial surveillance program (2006-09). J. Antimicrob. Chemother. 66, 2070-2074.

Gelfand, J.A., and Shapiro, L. (1993). Cytokines and sepsis: pathophysiology and therapy. New Horiz. 1, 13-22.

Giamarellou, H., and Poulakou, G. (2009). Multidrugresistant Gram-negative infections: what are the treatment options? Drugs 69, 1879-1901.

Hennessy, E. J., Parker, A. E., and O’Neill, L. A. (2010). Targeting toll-like receptors: emerging therapeutics? Nat. Rev. Drug Discov. 9, 293-307.

Holzheimer, R. G. (2001). Antibiotic induced endotoxin release and clinical sepsis: a review. J. Chemother. 13, 159-172.

Hotchkiss, R. S., Coopersmith, C. M., McDunn, J. E., and Ferguson, T. A. (2009). The sepsis seesaw: tilting toward immunosuppression. Nat. Med. 15, 496-497.

Hotchkiss, R. S., and Karl, I. E. (2003). The pathophysiology and treatment of sepsis. N. Engl. J. Med. 348, 138-150.

Iwagaki, A., Porro, M., and Pollack, M. (2000). Influence of synthetic antiendotoxin peptides on lipopolysaccharide (LPS) recognition and LPS-induced proinflammatory cytokine responses by cells expressing membrane-bound CD14. Infect. Immun. 68 1655-1663.

Jerala, R., and Porro, M. (2004). Endotoxin neutralizing peptides. Curr. Top. Med. Chem. 4, 1173-1184. 
Jones, W. II, Minei, J., Barber, A., fahey, T., and Shires, G. T. III. (1991). Splanchnic vasoconstriction and bacterial translocation after thermal injury. Am. J. Physiol. 261, H1190-H1196.

Jounai, N., Kobiyama, K., and Takeshita, F. (2012). Intracellular inflammatory sensors for foreign invaders and substances of self-origin. Adv. Exp. Med. Biol. 738, 60-78.

Kawata, T., Bristol, J. R., Rossignol, D. P., Rose, J. R., Kobayashi, S., Yokohama, H., Ishibashi, A., Christ, W. J., Katayama, K., Yamatsu, I., and Kishi, Y. (1999). E5531, a synthetic non-toxic lipid A derivative blocks the immunobiological activities of lipopolysaccharide. Br. J. Pharmacol. 127, 853-862.

Kim, K. S., Kang, J. H., Cross, A. S., Kaufman, B., Zollinger, W., and Sadoff, J. (1988). Functional activities of monoclonal antibodies to the $\mathrm{O}$ side chain of Escherichia coli lipopolysaccharides in vitro and in vivo. J. Infect. Dis. 157, 47-53.

Kwa, A., Kasiakou, S. K., Tam, V. H., and Falagas, M. E. (2007). Polymyxin B: similarities to and differences from colistin (polymyxin E). Expert. Rev. Anti. Infect. Ther. 5, 811-821.

Le Roy, D., Di Padova, F., Tees, R., Lengacher, S., Landmann, R., Glauser, M. P., Calandra, T., and Heumann, D. (1999). Monoclonal antibodies to murine lipopolysaccharide (LPS)-binding protein (LBP) protect mice from lethal endotoxemia by blocking either the binding of LPS to LBP or the presentation of LPS/LBP complexes to CD14. J. Immunol. $162,7454-7460$.

Lim, L. M., Ly, N., Anderson, D., Yang, J. C., MacAnder, L., Jarkowski, A. III, Forrest, A., Bulitta, J. B., and Tsuji, B. T. (2010). Resurgence of colistin: a review of resistance, toxicity, pharmacodynamics, and dosing. Pharmacotherapy 30, 1279-1291.

Martin, G. S., Mannino, D. M., Eaton, S., and Moss, M. (2003). The epidemiology of sepsis in the United States from 1979 through 2000. N. Engl. J. Med. 348, 1546-1554.

Michalopoulos, A., and Falagas, M. E. (2008). Colistin and polymyxin B in critical care. Crit. Care Clin. 24 , 377-391.

Mizuyachi, K., Hara, K., Wakamatsu, A., Nohda, S., and Hirama, T. (2011). Safety and pharmacokinetic evaluation of intravenous colistin methanesulfonate sodium in Japanese healthy male subjects. Curr. Med. Res. Opin. 27, 2261-2270.

Morrison, D. C., and Jacobs, D. M. (1976). Binding of polymyxin B to the lipid A portion of bacterial lipopolysaccharides. Immunochemistry 13, 813-818.

Moss, M., and Martin, G. S. (2004). A global perspective on the epidemiology of sepsis. Intensive Care Med. $30,527-529$.

Nakamura, T., Ebihara, I.,Shoji, H., Ushiyama, C., Suzuki, S., and Koide, H. (1999). Treatment with polymyxin B-immobilized fiber reduces platelet activation in septic shock patients: decrease in plasma levels of soluble P-selectin, platelet factor 4 and beta-thromboglobulin . Inflamm. Res. 48, 171-175.

Nakamura, T., Ushiyama, C., Suzuki, Y., Inoue, T., Shoji, H., Shimada, N., and Koide, H. (2003). Combination therapy with polymyxin B-immobilized fibre haemoperfusion and teicoplanin for sepsis due to methicillin-resistant Staphylococcus aureus. J. Hosp. Infect. 53, 58-63.

Nakamura, T., Ushiyama, C., Suzuki, Y., Shoji, H., Shimada, N., and Koide, H. (2002). Hemoperfusion with polymyxin B immobilized fibers for urinary albumin excretion in septic patients with trauma. ASAIO J. 48, 244-248.

Nation, R. L., and Li, J. (2009). Colistin in the 21st century. Curr. Opin. Infect. Dis. 22, 535-543.

Newton, K., and Dixit, V. M. (2012). Signaling in innate immunity and inflammation. Cold Spring Harb. Perspect. Biol. 4, a006049.

Nikaido, H., and Vaara, M. (1985). Molecular basis of bacterial outer membrane permeability. Microbiol. Rev. 49, 1-32.

Olive, C. (2012). Pattern recognition receptors: sentinels in innate immunity and targets of new vaccine adjuvants. Expert. Rev. Vaccines. 11, 237-256.

Oliveira, M. S., Prado, G. V., Costa, S. F., Grinbaum, R. S., and Levin, A. S. (2009). Polymyxin B and colistimethate are comparable as to efficacy and renal toxicity. Diagn. Microbiol. Infect. Dis. 65, 431-434.

Palsson-McDermott, E. M., and O’Neill, L. A. (2004). Signal transduction by the lipopolysaccharide receptor, toll-like receptor-4. Immunology 113, 153-162.

Peterson, A., Hancock, R. E. W., and McGroarty, E. J. (1985). Binding of polycationic antibiotics and polyamines to lipopolysaccharides of Pseudomonas aeruginosa. J. Bacteriol. 164, 1256-1261.

Porro, M. (1994). Structural basis of endotoxin recognition by natural polypeptides. Trends. Microbiol. 2, 65-66.

Porro, M., Rustici, A., Velucchi, M., Agnello, D., Villa, P., and Ghezzi, P. (1998). Natural and synthetic polypeptides that recognize the conserved lipid a binding site of lipopolysaccharides. Prog. Clin. Biol. Res. 397, 315-325.

Ramasubban, S., Majumdar, A., and Das, P. S. (2008). Safety and efficacy of polymyxin B in multidrug resistant Gram-negative severe sepsis and septic shock. Indian J. Crit. Care Med. 12, 153-157.

Ranieri, V. M., Thompson, B. T., Barie, P. S., Dhainaut, J. F., Douglas, I. S., Finfer, S., Gardlund, B., Marshall, J. C., Rhodes, A., Artigas, A., Payen, D., Tenhunen, J., Al Khalidi, H. R., Thompson, V., Janes, J., Macias, W. L., Vangerow, B., and Williams, M. D. (2012). Drotrecogin alfa (activated) in adults with septic shock. N. Engl. J. Med. 366, 2055-2064.

Rietschel, E. T., Brade, H., Brade, L., Brandenburg, K., Schade, U. F., Seydel, U., Z,hringer, U., Galanos, C., Lüderitz, O., Westphal, O., Labischinski, H., Kusumoto, S., and Shiba, T. (1987). Lipid A, the endotoxic center of bacterial lipopolysaccharides: Relation of chemical structure to biological activity. Prog. Clin. Biol. Res. 231, 25-53.

Rietschel, E. T., Kirikae, T., Schade, F. U., Mamat, U. Schmidt, G., Loppnow, H., Ulmer, A. J., Zähringer U., Seydel, U., Di Padova, F., Schreier, M., and Brade, H. (1994). Bacterial endotoxin: molecular relationships of structure to activity and function. FASEB J. $8,217-225$.

Rimmele, T., and Kellum, J. A. (2011). Clinical review: blood purification for sepsis. Crit. Care 15, 205.

Rocke, D., Gaffin, S., Wells, M., Koen, Y., and BrockeUtine, J. (1987). Endotoxemia associated with cardiopulmonary bypass. J. Thorac. Cardiovasc. Surg. 93, 832-837.

Rocque, W. J., Fesik, S. W., Haug, A., and McGroarty, E. J. (1988). Polycation binding to isolated lipopolysaccharide from antibiotic-hypersusceptible mutant strains of Escherichia coli. Antimicrob. Agents Chemother. 32, 308-313.
Rose, J. R., Mullarkey, M. A., Christ, W. J., Hawkins, L. D., Lynn, M., Kishi, Y., Wasan, K. M., Peteherych, K., and Rossignol, D. P. (2000). Consequences of interaction of a lipophilic endotoxin antagonist with plasma lipoproteins. Antimicrob. Agents Chemother. $44,504-510$.

Rustici, A., Velucchi, M., Faggioni, R., Sironi, M., Ghezzi, P., Quataert,S., Green, B., and Porro, M. (1993). Molecular mapping and detoxification of the lipid A binding site by synthetic peptides. Science 259, 361-365.

Saadia, R., Schein, M., MacFarlane, C., and Boffard, K. (1990). Gut barrier function and the surgeon. Br. J. Surg. 77, 487-492.

Scott, M. G., Vreugdenhil, A. C., Buurman, W. A., Hancock, R. E., and Gold, M. R. (2000). Cationic antimicrobial peptides block the binding of lipopolysaccharide (LPS) to LPS binding protein. J. Immunol. 164, 549-553.

Siegel, J. P. (1995). Antiendotoxin antibodies. Ann. Intern. Med. 122, 315-316.

Spapen, H., Jacobs, R., Van, G. V., Troubleyn, J., and Honore, P. M. (2011). Renal and neurological side effects of colistin in critically ill patients. Ann. Intensive. Care 1, 14.

Stokes, D. C., Shenep, J. L., Fishman, M. L., Hidner, W. K., Bysani, G. K., and Rufus, K. (1989). Polymyxin B prevents lipopolysaccharide-induced release of tumor necrosis factor- $\alpha$ from alveolar macrophages. J. Infect. Dis. 160, 52-57.

Storm, D. R., and Rosenthal, K. (1977). Polymyxin and related peptide antibiotics. Annu. Rev. Biochem. 46, 723-763.

Thomas, L. (1975). The Lives of a Cell. New York: Penguin Books.

Tidswell, M., and Larosa, S. P. (2011). Toll-like receptor-4 antagonist eritoran tetrasodium for severe sepsis. Expert. Rev. Anti. Infect. Ther. 9, 507-520.

Vaara, M. (1983). Polymyxin B nonapeptide complexes with lipopolysaccharide. FEMS Microbiol. Lett. 18, 117-121.

Vaara, M., and Vaara, T. (1983). Polycations as outer membrane disorganizing agents. Antimicrob. Agents Chemother. 24, 114-122.

Vaarala, O., Vaara, M., and Palosuo, T. (1988). Effective inhibition of cardiolipin-binding antibodies in gramnegative infections by bacterial lipopolysaccharide. Scand. J. Immunol. 28, 607-612.

Viljanen, P., Matsunaga, H., Kimura, Y., and Vaara, M. (1991). The outer membrane permeability-increasing action of deacylpolymyxins. J. Antibiot. 44, 517-523.

Wang, H., Bloom, O., Zhang, M., Vishnubhakat, J. M., Ombrellino, M., Che, J., Frazier, A., Yang, H., Ivanova, S., Borovikova, L., Manogue, K. R., Faist, E., Abraham, E., Andersson, J., Andersson, U., Molina, P. E., Abumrad, N. N., Sama, A., and Tracey, K. J. (1999). HMG-1 as a late mediator of endotoxin lethality in mice. Science 285, 248-251.

Wenzel, R. P., and Edmond, M. B. (2012). Septic shock evaluating another failed treatment. N. Engl. J. Med. $366,2122-2124$

Williams, S. C. (2012). After Xigris, researchers look to new targets to combat sepsis. Nat. Med. 18, 1001.

Wittebole, X., Castanares-Zapatero, D., and Laterre, P. F. (2010). Toll-like receptor 4 modulation as a strategy to treat sepsis. Mediators Inflamm. 2010, 1-9.

Yao, Y. M., Tian, H. M., Sheng, Z. Y., Wang, Y. P., Yu, Y., Sun, S. R., and Xu, S. H. (1995). Inhibitory effects of low-dose polymyxin B on hemorrhage-induced endo- 
toxin/bacterial translocation and cytokine formation in rats. J. Trauma 38, 924-930.

Zavascki, A. P., Goldani, L. Z., Li, J., and Nation, R. L. (2007). Polymyxin B for the treatment of multidrugresistant pathogens: a critical review. J. Antimicrob. Chemother. 60, 1206-1215.

Zeni, F., Freeman, B., and Natanson, C. (1997). Antiinflammatory therapies to treat sepsis and septic shock: a reassessment. Crit. Care Med. 25, 1097-1100.

Ziegler, E. J. (1988). Protective antibody to endotoxin core: the emperor's new clothes? J. Infect. Dis. 158, 286-290.

Ziegler, E. J., Fisher, C. J. Jr., Sprung, C. L., Straube, R. C., Sadoff, J. C., Foulke, G. E., Wortel, C. H., Fink, M.
P., Dellinger, R. P., Teng, N. N. H., Allen, I. E., Berger, H. J., Knatterud, G. L., LoBuglio, A. F., Smith, C. R., and Study Group, A. S. (1991). Treatment of gramnegative bacteremia and septic shock with HA- 1A human monoclonal antibody against endotoxin - aA randomized, double-blind, placebo-controlled trial. N. Engl. J. Med. 324, 429-436.

Ziegler, E. J., McCutchan, J. A., Fierer, J., Glauser, M. P., Sadoff, J. C., Douglas, H., and Braude, A. I. (1982). Treatment of Gram-negative bacteremia and shock with human antiserum to a mutant Escherichia coli. N. Engl. J. Med. 307, 1225-1230.

Ziegler, E. J., and Smith, C. R. (1992). Anti-endotoxin monoclonal antibodies. N. Engl. J. Med. 326, 1165.
Received: 28 July 2012; accepted: 30 July 2012; published online: 15 August 2012.

Citation: David SA (2012) Antimicrobial peptides for Gram-negative sepsis: a case for the polymyxins. Front. Immun. 3:252. doi: 10.3389/fimmu.2012.00252

This article was submitted to Frontiers in Molecular Innate Immunity, a specialty of Frontiers in Immunology.

Copyright (c) 2012 David. This is an open-access article distributed under the terms of the Creative Commons Attribution License, which permits use, distribution and reproduction in other forums, provided the original authors and source are credited and subject to any copyright notices concerning any third-party graphics etc. 